\title{
Grazing systems, stocking rates, and cattle behavior in southeastern Wyoming
}

\author{
K.W. HEPWORTH, P.S. TEST, R.H. HART, J.W. WAGGONER, JR., AND M.A. SMITH
}

\section{Abstract}

Grazing systems and stocking rates are used to influence livestock grazing behavior with the intent of improving livestock and vegetation performance. In 1982, a study was initiated to determine effects of continuous, rotationally deferred, and shortduration rotation grazing and moderate and heavy stocking rates on steer gains, range vegetation, and distance traveled by and activity patterns of steers. Steers were observed from dawn to dark on 12 dates during 1983, 1984, and 1985, and activity recorded every 15 minutes. Eight steers per treatment (system $\times$ stocking rate combination) per date were observed in 1983 and 1984, and 10 per treatment in 1985. In 1984 and 1985, map locations of all steers were recorded at the same times as activity, and distance traveled summed from distances between successive map locations. In 1984, activity of 3 steers per treatment was electronically monitored during darkness. Steers grazed approximately $8.6 \mathrm{hr}$ per day during daylight and $1.6 \mathrm{hr}$ during darkness. Steers grazed an average of $8.9 \mathrm{hr} /$ day during daylight under moderate vs $8.1 \mathrm{hr}$ under heavy stocking, but stocking rate interacted with date in 1984 and grazing system in 1985. Steers traveled farther under continuous than under short-duration rotation grazing at both stocking rates in 1984 , but only at the high stocking rate in 1985 . Steers had to travel farther to water in the continuous pastures, and may have had to cover a greater area in an effort to select a more desirable diet, particularly under heavy stocking. These differences were not reflected in differences in gain among stocking rates or grazing systems.

Key Words: rangelands, beef steers, grazing behavior, grazing systems

Rotation grazing systems were developed to improve livestock performance and range condition (Sampson 1913, Merrill 1954, Hormay and Talbot 1961). Short-duration rotation grazing, more popularly called the Savory Grazing Method, claims to permit a doubling in stocking rate without a negative effect on livestock performance and with an improvement in forage production and range condition (Savory 1988). The claims put forth for the Savory Grazing Method have seldom been supported by research (Gammon 1984, Blackburn 1984, Heitschmidt 1986, Hart et al. 1988).

Much of the interest in grazing systems has focused on animal performance and range condition, but grazing systems also affect livestock grazing behavior. Behavior is the sum of an animal's reaction to its environment and its physiology, and may ultimately influence performance (Balph and Balph 1986). Pasture size, distance to water, animal density, and length of grazing period influence livestock behavior (Valentine 1947, Arnold and Dudzinski 1978, Ganskopp and Vavra 1987), and can be manipulated through the grazing systems discussed above. Grazing distribution, forage selection (plant parts, specific plants, and sites) and feeding behavior (bites/feeding station, steps between stations, daily distance traveled, and activity patterns) may be influenced by grazing systems and ultimately may impact animal performance and range

\footnotetext{
Authors are former research assistants, Dept. of Range Management, University of Wyoming, Laramie 82071; range scientist, USDA Agricultural Research Service, Cheyenne, Wyo. 82009; and animal nutritionist, Animal Science Dept., and associate professor, Dept. of Range Management, University of Wyoming. Hepworth's current address is P.O. Box 2607, Durango, Colo. 81302 .

Manuscript accepted 30 June 1990.
}

condition (Olson and Malechek 1988, Walker and Heitschmidt 1989).

In 1982 a planned 12-year grazing system and stocking rate study using cattle (Bos taurus) was initiated at the USDA's High Plains Grasslands Research Station west of Cheyenne, Wyo. The main objective of the study was to determine the effects of 3 grazing systems (continuous, rotationally deferred, and short-duration rotation) and 2 stocking rates (moderate and heavy) on steer gain and vegetative responses; results during the first 6 years (1982-87) were reported by Hart et al. (1988). However, the time steers devote to various activities and the distance they travel may explain the differences seen in gain and vegetation. The study reported in this paper was designed to test 3 hypotheses: (1) steers travel farther and spend more time grazing under heavy stocking, as increased utilization makes it more difficult for them to meet their nutrient requirements; (2) steers do not travel as far under short-duration rotation grazing, where pastures are subdivided into smaller paddocks; and (3) steers do not graze for a significant amount of time at night.

\section{Methods}

\section{Study Area}

The High Plains Grasslands Research Station is located approximately $10 \mathrm{~km}$ northwest of Cheyenne, Wyo. The area experiences wide daily and seasonal temperature fluctuations with the average growing season being 127 days. West winds predominate, blowing downslope off the Laramie Range. The climate is semi-arid; 1871-1984 average annual precipitation was $389 \mathrm{~mm}$ at nearby Cheyenne. The majority ( $70 \%$ ) of precipitation comes as wet snow and rain from April through September with May and June being the wettest months. Precipitation during the 3 years of the study was 151,131 , and $94 \%$ of normal (Hart et al. 1988).

Rolling hills of mixed grass prairie dominate the landscape at an elevation varying between 1,910 and $1,950 \mathrm{~m}$. Dominant soils are Ascalon and Altvan loams (mixed, mesic, Aridic Argiustolls), Cascajo gravelly loam (a mixed, mesic, Aridic Calciorthid), and Larim Variant gravelly loam (a mixed, mesic, Ustollic Haplargid).

Vegetation is dominated by grasses. Western wheatgrass (Pascopyron smithii Rydb.) and needleandthread (Stipa comata Trin. and Rupr.), cool-season mid-grasses, are considered decreasers. Blue grama (Bouteloua gracilis (H.B.K.) Griffiths) and buffalograss (Buchloe dactyloides) (Nutt.) Engelm.) are increasers. These species contribute the majority of forage available to cattle (Samuel and Howard 1982). Forage production was $1,670 \mathrm{~kg} / \mathrm{ha}$ in $1983,1,140$ in 1984, and 1,040 in 1985.

\section{Cattle Management Practices}

Three grazing systems were compared in this study:

(1) Season-long or continuous with no pasture subdivisions.

(2) Rotationally deferred with a different quarter of each pasture deferred each year until 1 September; then all 4 quarters were grazed until steers were removed from the pastures in October.

(3) Short duration rotation with each of 8 pasture subdivisions or paddocks grazed in rotation. These steers were rotated from paddock to paddock on a fixcd schedule in 1983 and 1984. Each paddock was grazed for 3 days at the beginning of the season, and the grazing period was increased to $7 \mathrm{davs}$ bv the end of the season. 
In 1985 the grazing periods varied from 2 to 11 days depending on forage growth rate and availability.

Two stocking rates were used, moderate (4 steer/12 ha) and heavy (4 steers/ 9 ha) in 1983 and 1984. The moderate stocking rate was approximately the SCS (1986) recommended rate for the condition of the sites; the heavy SR was approximately $33 \%$ higher. In 1985,5 steers were stocked on each moderate or heavy pasture.

A randomized block design with 2 replications was used. The factor blocked was topography; the first replication was on a steeper, predominantly north slope $(0-15 \%)$ while the second replication was on a more nearly level $(0-6 \%)$ southern exposure.

Steers used were of Hereford-Angus-Simmental or HerefordAngus-Charolais breeding. Initial average steer weights were 292 $\mathrm{kg}$ in 1983, 245 in 1984, and 249 in 1985.

Steers were weighed at the beginning of the grazing period and every 2 weeks thereafter. Weights were obtained following an overnight shrink period (no food or water) for 15 to 16 hours. Further details of experimental design and management can be found in Hart et al. (1988).

\section{Animal Grazing Activity}

Steer activity was observed from 1983 through 1985. Pastures were close enough that 1 person could watch the steers in 2 pastures at a time. In 1983 only 1 replication was done per day so it took 2 days to do both replications; observation dates were 19 and 22 July and 5 August, 9 and 12 August, 15 and 18 August, and 23 and 26 August. In 1984 and 1985 both replications were observed on the same day, on 27 June, 18 July, and 16 August 1984, and 14 June, 17 July, 15 August, and 19 September 1985.

Observation periods began at first light and ended when it was too dark to see cattle clearly, from approximately $30 \mathrm{~min}$ before sunrise to $30 \mathrm{~min}$ after sunset. Activity of each steer in each pasture was recorded at 15-minute intervals and categorized as grazing, resting, or traveling. Locations of each steer at each interval were plotted on scaled maps.

In 1984, we monitored night-time activity of steers from 1900 to 0700 the following morning (standard time), using Telonics tipswitch radio collars and a chart graph recorder. The recorder graphed signal strength and pulse rate or period. Signal strength varied with the movement of the steer while the period changed from shorter to longer as the steer lowered his head to graze. Activity of 1 steer per pasture in replication 1 was monitored from 13 to 16 August and from 20 to 24 August, and of 1 steer per pasture in replication 2 between 4 and 11 September 1984. We tried to monitor 2 steers per night but this was not always possible because of equipment failure. A more intensive study design was planned for 1985, but equipment failure early in the summer halted night work shortly after it began.

Distance traveled was obtained in 1984 and 1985 by totaling distances between successive observations throughout the day as plotted on scaled maps. No data from rotationally deferred pastures were obtained in 1985.

Time per day spent in each activity and travel distances were analyzed using standard ANOVA techniques for a split-plot design with 2 replications and 4 (1983 and 1984) or 5 (1985) samples within an experimental unit (pasture). Each year was analyzed separately, because different cattle were used each year, and cattle numbers and sampling dates varied among years. Dates within a year were handled as main treatments, with stocking rates and grazing systems as sub-treatments.

Time spent in each activity at night was analyzed as a randomized block with 3 blocks (rep 1, 13-16 August; rep 1, 20-24 August; and rep 2, 4-11 September). Rep and date effects were confounded within blocks.
Mean separations were performed with Duncan's multiple range test as appropriate. Significance is at the $P<0.05$ level.

\section{Results and Discussion}

\section{Animal Grazing Activity}

Steers spent significantly more time grazing under moderate than under heavy stocking in 1983 and in June and August 1984, but there were no differences between stocking rates in July 1984 (Table 1). The only case in which steers spent more time grazing

Table 1. Grazing and resting times of steers; effects of stocking rates, grazing systems, and dates, 1983-1985.

\begin{tabular}{|c|c|c|c|c|c|c|}
\hline $\begin{array}{l}\text { Stocking } \\
\text { rate }\end{array}$ & 1983 & $\begin{array}{c}27 \\
\text { June }\end{array}$ & $\begin{array}{c}-1984 \\
18 \\
\text { July }\end{array}$ & $\begin{array}{c}16 \\
\text { August }\end{array}$ & $\begin{array}{c}\text { Continu- } \\
\text { uous }\end{array}$ & $\begin{array}{c}5-\cdots- \\
\text { SD } \\
\text { rota- } \\
\text { tion }\end{array}$ \\
\hline $\begin{array}{l}\text { Moderate } \\
\text { Heavy }\end{array}$ & $\begin{array}{l}9.5 \mathrm{a} \\
7.3 \mathrm{~b}\end{array}$ & 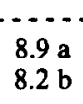 & $\begin{array}{l}\text { Grazi } \\
8.5 \mathrm{ah} \\
8.8 \mathrm{a}\end{array}$ & $\begin{array}{c}\mathrm{g}, \mathrm{hr} / \mathrm{day} \\
8.2 \mathrm{~b} \\
7.4 \mathrm{c}\end{array}$ & $\begin{array}{l}8.6 \mathrm{~b} \\
9.6 \mathrm{a}\end{array}$ & $8.8 \mathrm{~b}$ \\
\hline $\begin{array}{l}\text { Moderate } \\
\text { Heavy } \\
\text { Mean }\end{array}$ & $7.2 \mathrm{~b}$ & $\begin{array}{l}\cdots \\
\cdots \\
-2 \mathrm{a}\end{array}$ & $\begin{array}{c}\text { Resti } \\
-.- \\
-.- \\
7.2 \mathrm{a}\end{array}$ & $\begin{array}{c}\mathrm{hr} / \mathrm{da} \\
-- \\
- \\
5.3 \mathrm{~b}\end{array}$ & $\begin{array}{l}6.5 \mathrm{a} \\
5.6 \mathrm{~b}\end{array}$ & $\begin{array}{l}6.2 \mathrm{ab} \\
6.5 \mathrm{a}\end{array}$ \\
\hline
\end{tabular}

a,b Times within the same year and activity, followed by the same letter, are not significantly different ( $P>0.05$ ).

under heavy than moderate stocking occurred in 1985 under continuous grazing; under short-duration rotation grazing, no differences between stocking rates were observed. Resting time, as expected, was inversely related to grazing time, except in 1984 when no differences between stocking rates were observed on any date.

The marginal value theorem of Charnov (1976) postulates that a predator or grazer stops feeding in a "patch" when it can no longer meet its food needs efficiently in that location. Our results suggest that, under heavy stocking, a grazer may stop feeding entirely when it has consumed enough food to meet requirements for maintenance and some growth, because consuming more food for more growth would be energetically inefficient.

Only in 1984 did date have an impact on grazing or resting time. Steers spent less time resting and, under heavy stocking, less time grazing in August than in June or July. This did not seem to be related to shorter days, as no differences between dates were noted in 1985 when the last observations were taken 19 September, when days were even shorter. Grazing system affected grazing and rest time only in 1985 at the heavy stocking rate, when steers spent more time grazing and less time resting under continuous than under short-duration rotation grazing.

All 18 monitored steers continued grazing later than 30 minutes after sunset (when visual observations ceased), for an average of 37 min. Two of the 18 began grazing earlier than 30 minutes before sunrise (when visual observations began), for 10 and 45 minutes. Steers grazed an average of $3 \mathrm{hr}$ and $36 \mathrm{~min}$ from 1900 to 0700, with no significant differences among grazing rates or systems. However, this time includes daylight hours between dawn and 0700 and between 1900 and darkness.

Whether steers graze for a significant time during the night depends on the definition of "night grazing". If we exclude from the definition grazing which represents a late ending or an early beginning of the last and first periods of daytime grazing, respectively, then very few steers grazed for long and some did not graze at all during the night.

In 1984,12 of the 18 monitored steers engaged in true "nighttime grazing", i.e., grazing that did not continue from or into a daytime grazing period. Nine steers grazed for 1 period during the 
night, and 3 steers grazed for 2 periods. Average length of time spent grazing among these 12 steers was $1 \mathrm{hr}$ and $28 \mathrm{~min}$; when all 18 steers were included in the calculations, average grazing time was $58 \mathrm{~min}$. When grazing time immediately after nightfall and immediately before daybreak is added, mean total grazing time during darkness equalled $98 \mathrm{~min}$ or $1.6 \mathrm{hr}$. Again, no differences were detected among stocking rates or systems.

Arnold and Dudzinski (1978) discussed the importance night monitoring might play in detecting total time spent in various activities. Stockdale and King (1983) along with Bjugstad and Dalrymple (1968) found cattle did not spend a significant amount of time grazing at night. However, Hull et al. (1960), Dwyer (1961), Gary et al. (1970), and Stricklin et al. (1976) found that cattle did graze at night.

Average grazing time (day plus night) was $10.2 \mathrm{hr} / \mathrm{da}$, comparable to times reported in other studies. Heifers on crested wheatgrass (Agropyron desertorum [Fisch.] Schult. and A. cristatum [L.] Gaertn.) grazed $10.7 \mathrm{hr} /$ da under short-duration grazing and $9.8 \mathrm{hr} / \mathrm{da}$ under season-long grazing (Olson and Malechek 1988). But calves on perennial ryegrass (Lolium perenne L.) grazed longer under continuous grazing, $8.9 \mathrm{hr} / \mathrm{da}$ vs $7.8 \mathrm{hr} / \mathrm{da}$ under stripgrazing (Jamieson and Hodgson 1979a and b). Grazing time of yearling steers on Asiatic bluestem (Bothriocloa ischaemum [L.] Keng. and B. caucasica [Trin.] C.E. Hubb.) decreased from 10.5 to $9.5 \mathrm{hr} / \mathrm{da}$ as herbage mass increased from 2 to 4.5 tonnes of organic matter per ha (Forbes and Coleman 1987). Dry cows on Setaria anceps grazed $10.5 \mathrm{hr} / \mathrm{da}$ (Chacon and Stobbs 1976).

\section{Travel Time and Distance}

Average travel time was $35 \mathrm{~min}$ or $0.6 \mathrm{hr} /$ day, with no significant differences among stocking rates, grazing systems, or dates. Travel time was highly variable, perhaps because considerable travel could occur in the 15 minutes between observations. For example, steers could travel to or from water in most of the pastures within 15 minutes, and escape observation entirely. However, changes in location between successive observations enabled us to estimate travel distance even when travel was not observed.

In 1984 steers traveled farther under continuous or rotationally deferred than under short-duration rotation grazing (Table 2). In

Table 2. Distances travelled by steers; effects of stocking rates and grazing systems, 1984 and 1985.

\begin{tabular}{lccc}
\hline & & & \\
System & 1984 & Moderate & Heavy \\
stocking & stocking \\
\hline Continuous & $3.0 \mathrm{a}$ & $2.4 \mathrm{ab}$ & $2.7 \mathrm{a}$ \\
Short duration rotation & $1.8 \mathrm{~b}$ & $2.1 \mathrm{bc}$ & $1.7 \mathrm{c}$ \\
Rotationally deferred & $2.9 \mathrm{a}$ & $\ldots \ldots$ & $\cdots$ \\
\hline
\end{tabular}

ab Means in the same year, followed by the same letter, are not significantly different $(P>0.05)$.

1985, steers traveled farther under continuous than under shortduration rotation grazing at heavy but not at moderate stocking. Travel distance apparently was related to pasture size. Continuously grazed pastures were 8 times as large as short-duration rotation paddocks, and rotationally deferred pastures were 6 (during deferment) or 8 times (after the deferred quarter was opened) as large as short-duration rotation paddocks at the same stocking rate.

Although steers traveled approximately $1.0 \mathrm{~km} /$ day farther under continuous than under short-duration rotation grazing, this difference was not reflected in any difference in steer gain. Cook (1970) reported that Brody (1945) calculated a net energy requirement of 33 to 35 kilocalories per $100 \mathrm{lb}$ of body weight for a grazing animal to walk a mile, and that Clapperton (1964) calculated a requirement of 39 to 41 kilocalories per $100 \mathrm{lb}$ per mile. This equates to an average figure of $51 \mathrm{kilocalories} / \mathrm{km}$ of travel $/ 100 \mathrm{~kg}$ of body weight. Garrett et al. (1959) reported that steers gaining about 2 pounds/day required about 1900 kilocalories per pound gain, equal to about 4200 kilocalories $/ \mathbf{k g}$ of gain. Thus the difference of $1.0 \mathrm{~km}$ in travel between the 2 systems, on steers weighing an average of $353 \mathrm{~kg}$ over the 2 grazing seasons, would be equivalent to a difference of $43 \mathrm{~g}$ of average daily gain, a difference too small to detect in this study.

This conclusion is supported by Walker et al. (1989), who calculated that the energy cost of grazing and travel accounted for only 0.44 and $0.15 \%$ of the variation in simulated weight change in cows and calves, respectively. However, Hart et al. (1989) noted that cows which had to travel a maximum of $5.6 \mathrm{~km}$ to water under continuous grazing gained $0.16 \mathrm{~kg} /$ day less than cows which had to travel no more than $1.6 \mathrm{~km}$ to water under continuous or shortduration rotation grazing. Thus distance to water had a significant impact on gains while grazing system did not.

In conclusion, steers generally spent less time grazing under heavy than under moderate stocking; this was reflected in lower gains under the former. This suggests that decreased grazing time might serve as an early warning of overstocking, but the difference between the 2 stocking rates averaged only $0.7 \mathrm{hr}$ per day, and varied somewhat among grazing systems, years, and dates within years (Table 1). Grazing systems had no consistent effect on grazing time.

Steers did not travel as far under short-duration rotation grazing as under continuous or rotationally deferred grazing. This difference was not reflected in gains, but Hart et al. (1989) showed that greater travel distance can reduce gains if the increase is large enough. Significant improvements in gain might result from subdividing large pastures, regardless of the grazing system applied.

\section{Literature Cited}

Arnold, G.W., and M.L. Dudzinski. 1978. Ethology of free-ranging domestic livestock. Elsevier Sci. Publ. Co, New York.

Balph, D.F., and M.H. Balph. 1986. The application of behavioral concepts to livestock management. Utah Sci. 47:78-85.

Bjugstad, A.J., and A.V. Dalrymple. 1968. Behavior of beef heifers on Ozark ranges. Univ. of Missouri Agr. Exp. Sta. Bull. 870.

Blackburn, W.H. 1984. Impacts of grazing intensity and specialized grazing systems on watershed characteristics and responses. p. 927-983. In: NRC/NAS, Developing strategies for rangeland management. Westview Press, Boulder, Colo.

Brody, S. 1945. Bioenergetics and growth. Reinhold Publ. Co., New York. Chacon, E., and T.H. Stobbs. 1976. Influence of progressive defoliation of a grass sward on the eating behavior of cattle. Aust. J. Agr. Res. 27:709-727.

Charnov, E.L. 1976. Optimal foraging, the marginal value theorem. Theor. Pop. Biol. 9:129-136.

Clapperton, J.L. 1964. The energy metabolism of sheep walking on the level and on gradients. Brit. J. Nutr. 18:47-54.

Cook, C.W. 1970. Energy budget of the range and range livestock. Colorado State Univ. Exp. Sta. Bull. TB109.

Dwyer, D.D. 1961. Activities and grazing preferences of cows with calves in northern Osage County, Oklahoma. Oklahoma State Univ. Agr. Exp. Sta. Bull. B-588.

Forbes, T.D.A., and S.W. Coleman. 1987. Herbage intake and ingestive behavior of grazing cattle as influenced by variation in sward characteristics. p. 141-152. In: E,P. Horn, J. Hodgson, J.J. Mott, and R.W. Brougham (eds.), Proc. Special Session on Grazing Lands Research. Plant-Animal Interface. Winrock. Internat, Morrilton, Ark.

Gammon, D.M. 1984. An appraisal of short duration grazing as a method of veld management. Zimbabwe Agr. J. 81:59-64.

Ganskopp, D., and M. Vavra. 1987. Slope use by cattle, feral horses, deer, and bighorn sheep. Northwest Sci. 60:74-81.

Garrett, W.N., J.H. Meyer, and G.P. Lofgreen. 1959. The comparative energy requirements of sheep and cattle for maintenance and gain. $J$. Anim. Sci. 18:528-546.

Gary, L.A., G.W. Sherritt, and E.B. Hale. 1970. Behavior of Charolais cattle on pasture. J. Anim. Sci. 30:203-205. 
Hart, R.H., M.J. Samuel, P.S. Test, and M.A. Smith. 1988. Cattle, vegetation, and economic responses to grazing systems and grazing pressure. $J$. Range Manage. 41:282-286.

Hart, R.H., M.J. Samuel, J.W. Waggoner Jr., and M.A. Smith، 1989. Comparisons of grazing systems in Wyoming. J. Soil Water Cons. 44:344-347.

Heitschmidt, R.K. 1986. Short duration grazing at the Texas Experimental Ranch. p. 91-102. In: J.A. Tiedeman (ed.), Short duration grazing. Washington State Univ., Pullman, Washington.

Hormay, A.L., and M.W. Talbot. 1961. Rest-rotation grazing-a new management system for perennial bunchgrass ranges. USDA Prod. Res. Rep. 51.

Hull, J.L., G.P. Lofgreen, and J.H. Meyer. 1960. Continuous vs. intermittent observations in behavior studies with grazing cattle. J. Anim. Sci. 19:1204-1207.

Jamieson, W.S., and J. Hodgson. 1979a. The effect of daily herbage allowance and sward characteristics upon the ingestive behaviour and herbage intake of calves under strip-grazing management. Grass \& Forage Sci. 34:261-271.

Jamieson, W.S., and J. Hodgson. 1979b. The effects of variation in sward characteristics upon the ingestive behaviour and herbage intake of calves and lambs under a continuous stocking management. Grass \& Forage Sci. 34:273-282.

Merrill, L.B. 1954. A variation of deferred rotation grazing for use under southwest range conditions. J. Range Manage. 7:152-154.
Olson, K.C., and J.C. Malechek. 1988. Heifer nutrition and growth on short duration grazed crested wheatgrass. J. Range Manage. 41:259-263.

Sampson, A.W. 1913. Range improvement by deferred and rotation grazing. USDA Bull. 34.

Samuel, M.J., and G.S. Howard. 1982. Botanical composition of summer cattle diets on the Wyoming high plains. J. Range Manage. 35:305-308

Savory, A. 1988. Holistic resource management. Island Press, Covelo, California.

Stockdale, C.R., and K.R. King. 1983. Effect of stocking rate on the grazing behavior and fecal output of lactating dairy cows. Grass and Forage Sci. 38:215-228.

Stricklin, W.R., L.L. Wilson, and H.B. Graves. 1976. Feeding behavior of Angus and Charolais-Angus cows during summer and winter. J. Anim Sci. 43:721-732.

Valentine, K.A. 1947. Distance from water as a factor in grazing capacity of rangeland. J. Forest 45:749-754.

Walker. J.W., and R.K. Heitschmidt. 1989. Some effects of a rotational grazing treatment on cattle grazing behavior. J. Range Manage. 42:337-342.

Walker, J.W., J.W. Stuth, and R.K. Heitschmidt. 1989. A simulation approach for evaluating field data from grazing trials. Agr. Sys 30:301-316. 